\title{
Development of a monoclonal antibody specific to yellow head virus (YHV) from Penaeus monodon
}

\author{
Paisarn Sithigorngul ${ }^{1, *}$, Phudhi Chauychuwong ${ }^{2}$, Weerawan Sithigorngul', \\ Siwaporn Longyant ${ }^{1}$, Parin Chaivisuthangkura ${ }^{1}$, Piamsak Menasveta ${ }^{2-4}$ \\ ${ }^{1}$ Department of Biology, Faculty of Science, Srinakharinwirot University, Bangkok 10110, Thailand \\ ${ }^{2}$ Marine Biotechnology Research Unit, National Center for Genetic Engineering and Biotechnology, Ministry of Science, \\ Technology and Environment, Bangkok 10400, Thailand \\ ${ }^{3}$ Aquatic Resources Research Institute, and ${ }^{4}$ Department of Marine Science, Faculty of Science, Chulalongkorn University, \\ Bangkok 10330, Thailand
}

\begin{abstract}
A monoclonal antibody specific to yellow head virus (YHV) was produced from a mouse immunized with gill extracts prepared from laboratory-reared Penaeus monodon dually infected with YHV and white spot syndrome virus (WSSV). One clone designated V3-2B specifically bound to native and SDS-treated viral specific antigens. Immunocytochemical studies of infected gills revealed viral specific immunoreactivities in the cytoplasm of gill tissue and in haemocytes. No antibody binding was observed in gills from non-infected shrimp. In addition, immunocytochemical examination of tissues from shrimp experimentally infected with YHV gave a positive reaction, while tissues from uninfected control shrimp or shrimp experimentally infected with WSSV did not. Western blot analysis indicated that the antibody reacted with a protein of approximately $135 \mathrm{kD}$ that was present only in shrimp infected with YHV. In dot-blot indirect immunoperoxidase assays, the antibody was able to detect viral associated antigen in diluted haemolymph up to 1:50 dilution and in an ammonium sulfate precipitate of haemolymph up to 1:1000 dilution. The results suggested that this antibody might be useful for development of effective diagnostic techniques for both heavy and mild YHV infections in shrimp.
\end{abstract}

KEY WORDS: Immunocytochemistry $\cdot$ Monoclonal antibodies $\cdot$ Penaeus monodon $\cdot$ Yellow head virus (YHV)

Resale or republication not permitted without written consent of the publisher

\section{INTRODUCTION}

Shrimp diseases, especially viral infections, have caused major economic losses in Thai shrimp farming during the past decade (Flegel et al. 1997). Yellow head virus (YHV) and white spot syndrome virus (WSSV) are the most highly virulent of the causative agents, since they result in massive mortality of $P e-$ naeus monodon, the principal penaeid species cultured in Thailand. Recent attempts to prevent and control these 2 diseases have relied primarily on detection, diagnosis and removal of infected shrimp. PCR (polymerase chain reaction) is now widely used for WSSV detection, while RT-PCR (reverse transcrip-

*E-mail: paisarn@psm.swu.ac.th
tase-PCR) tests are under development for YHV detection (Wongteerasupaya et al. 1997, Lightner \& Redman 1998, Cowley et al. 1999). Although these PCR techniques are highly sensitive for virus detection, there are practical limitations to their widespread application. These limitations include needs for special equipment and well-trained personnel. Consequently, assay costs are expensive for small sample numbers and this can limit PCR use.

An alternative method to PCR is histopathological examination and symptomatic diagnosis (Wongteerasupaya et al. 1995, Lightner \& Redman 1998, Mohan et al. 1998, Park et al. 1998), but this also requires experienced personnel. In addition, diagnosis of early infections is difficult and unreliable using this approach. Moreover, field samples of shrimp are usually not well preserved and pathogenic symptoms may be incor- 
rectly assigned to other causes, such as bacterial infection. These limitations are the main reasons for incomplete epidemiological data for WSSV and YHV infections.

Immunological techniques are widely used for diagnosis of many viral diseases in both human medicine and agricultural applications. In addition to their high sensitivity and accuracy, immunological methods can be simplified to obtain results quickly at relatively low cost. The technology is also simple and easily used by relatively untrained personnel. Pregnancy test strips based on HCG (humans chorionic gonadotropin) detection in urine constitute one example of the application of this technique.

Several attempts to produce antisera against YHV and WSSV have been recently reported (Nadala et al. 1997, 1998, Loh et al. 1998). However, the antisera assay required the use of Western blot analysis, which is not easily adaptable to field examination. Successful development of monoclonal antibodies (MAb) to YHV and WSSV with sufficient specificity for diagnostic application have not yet been reported. Moreover, problems with MAb specificity have been reported with both IHHNV (infectious hypodermal and haematopoietic necrosis virus) (Lightner \& Redman 1998) and YHV (J. Kasornchandra pers. comm.). In both cases, specificity problems were related to the fact that the MAb obtained were of the IgM type.

The present work describes the development of a specific MAb of the IgG type against YHV and its use in the detection of YHV by dot-ELISA and immunocytochemistry.

\section{MATERIALS AND METHODS}

Experimental viral infection and immunogen preparation. Juvenile Penaeus monodon (25 to $30 \mathrm{~g}$ ) from farms near Bangkok were held in 3001 fiberglass tanks with 20 ppt seawater, ambient temperature and a natural photoperiod. WSSV was prepared from gills of $P$. monodon diagnosed with natural infections of WSSV (kindly provided by the Aquatic Animal Health Research Institute, Royal Thai Department of Fisheries, Bangkok). Gills of infected shrimp were homogenized in $2 \times$ L15 (Leibovit's L15 medium, Gibco $\mathrm{BBL}$ ) and centrifuged at $3000 \times g$ for $15 \mathrm{~min}$ to remove debris; the supernatant was then filtered through a sterile $0.22 \mu \mathrm{m}$ membrane filter. This viral suspension was diluted (1:10) and injected via the arthrodial membrane of the second walking leg at $50 \mu$ shrimp $^{-1}$. When infected shrimp showed signs of heavy infection, such as feeding cessation and slow movement ( 2 to $4 \mathrm{~d}$ ), haemolymph was drawn from the arthrodial membrane of the fourth walking leg using a syringe with a 22 gauge needle. Haemolymph was diluted to double volume with modified Alsever solution (55 mM trisodium citrate; $145 \mathrm{mM} \mathrm{NaCl}, \mathrm{pH} 6.1$ ), centrifuged at $3000 \times g$ to remove haemocytes and stored at $-20^{\circ} \mathrm{C}$ until used.

Gills from moribund shrimp were also collected, fixed in Bouin or Davidson's fixative (Lightner 1996) for immunocytochemical study, or frozen for viral preparation. Approximately $5 \mathrm{~g}$ of gills from infected shrimp were homogenized in $40 \mathrm{ml}$ of $2 \times$ PBS $(0.3 \mathrm{M}$ phosphate buffered saline, $\mathrm{pH} 7.2$, modified from Hudson \& Hay 1976) using a homogenizer (IKA lab Technik). Cell debris was removed by centrifugation at $10000 \times g$ for $1 \mathrm{~h}$ at $4^{\circ} \mathrm{C}$. The supernatant was subsequently centrifuged at $100000 \times g$ for $1 \mathrm{~h}$ at $4^{\circ} \mathrm{C}$ using an ultracentrifuge (Sorvall Pro 80). The pellet was resuspended in $2 \mathrm{ml}$ of $2 \times \mathrm{PBS}$, divided into small aliquots and stored at $-80^{\circ} \mathrm{C}$. Haemolymph and gill preparations from non-infected shrimp were prepared in the same manner.

Tissues fixed in Davidson's fixative were embedded in paraffin, sectioned and stained with haematoxylin and eosin Y (H\&E) (Lightner 1996) for histological examination for the presence of WSSV and YHV using the criteria described by Lightner (1996). The gill extracts and haemolymph extracts were also tested for WSSV by PCR (Kanchanaphum et al. 1998). RT-PCR for YHV was not carried out because of unavailability of the technique in our laboratory.

Immunization. Three Swiss mice were injected intraperitoneally with gill extract from the experimentally infected shrimp mixed with complete Freund's adjuvant in a 1:1 ratio. They were subsequently injected with this gill extract mixed with incomplete Freund's adjuvant 3 times at 2 wk intervals. One week after the third injection, mouse antiserum was collected and tested against non-infected and infected gill extracts by dot-blot. The best performing mouse was boosted $3 \mathrm{~d}$ before hybridoma production.

Hybridoma production. A cell fusion procedure was adapted from the method developed by Köhler \& Milstein (1976), with modifications described by Mosmann et al. (1979). A P3X myeloma cell line was used as a fusion partner. Fusion products from one mouse were plated on 30 microculture plates (96 wells). After identification of the positive clones by screening methods described below, cells were re-cloned by the limited dilution method.

Screening methods. Dot-blots: Gill extracts (10 mg $\mathrm{ml}^{-1}$ ) from non-infected and infected shrimp in both untreated (native) and SDS- $\beta$ mercaptoethanol treated forms were used for screening. Gill extract antigens $\left(1 \mu \mathrm{spot}^{-1}\right)$ were applied to a nitrocellulose membrane. The membrane was baked at $60^{\circ} \mathrm{C}$ for $10 \mathrm{~min}$ and subsequently incubated in hybridoma conditioned media 
from each clone (1:20 in 5\% Blotto) for $3 \mathrm{~h}$ to overnight. After extensive washing in diluted Blotto, the membrane was incubated in horseradish peroxidase labelled goat anti-mouse IgG that was heavy and light chain specific (GAM-HRP; Biorad) at 1:1000 dilution for $3 \mathrm{~h}$ to overnight. The membrane was washed in Blotto and incubated in a substrate mixture containing $0.03 \%$ diaminobenzidine, $0.006 \%$ hydrogen peroxide, $0.05 \%$ cobalt chloride in PBS for 5 min. Hybridoma clones that displayed immunoreactivity against infected gill extract, but did not react with gill extract from noninfected shrimp were confirmed for viral specificity by immunocytochemistry, recloned and cryopreserved for further investigation.

Immunocytochemistry: Gills from infected and noninfected live shrimp were dissected, fixed in Bouin fixative solution for $24 \mathrm{~h}$ and processed for paraffin sectioning. Serial sections ( $8 \mu \mathrm{m}$ thickness) were prepared and processed for indirect immunoperoxidase staining using various MAbs and GAM-HRP diluted to 1:1000 with $10 \%$ calf serum in PBS. Peroxidase activity was revealed by incubation with $0.03 \%$ DAB and $0.006 \%$ $\mathrm{H}_{2} \mathrm{O}_{2}$ in PBS. Preparations were counter-stained with $H \& E$, dehydrated in a graded ethanol series, cleared in xylene and mounted in permount. Viral localization in various tissues from non-infected and infected shrimp was also determined in the same manner.

To confirm the specificity of the MAb, immunocytochemistry tests were also performed on tissue sections from normal uninfected shrimp and shrimp experimentally infected with single virus preparations of YHV or WSSV. The sections were derived from paraffin embedded tissue that had been fixed in Davidson's fixative and processed as outlined by Lightner (1996). These embedded tissue blocks were kindly provided by T. W. Flegel, Mahidol University, Bangkok. He had confirmed the presence of characteristic YHV and WSSV lesions by histological examination of H\&E stained tissue sections from the blocks.

Viral antigen detection by monoclonal antibodies. Haemolymph from infected shrimp was serially diluted with haemolymph from non-infected shrimp. Approximately $1 \mu$ of each dilution was applied to a nitrocellulose strip and processed for dot-ELISA as described above. Final dilutions observed by this method were determined by comparison with negative controls, which consisted of haemolymph from normal, uninfected shrimp.

Protein isolation by ammonium sulfate precipitation. Proteins and virus in various dilutions of haemolymph were precipitated with $33 \%$ ammonium sulfate for $2 \mathrm{~h}$ at $4^{\circ} \mathrm{C}$. The precipitate was separated by centrifugation at $3000 \times g$ with a clinical centrifuge, washed once with $33 \%$ ammonium sulfate and then resuspended in PBS. The supernatants, both prior to and after washing, were combined. Saturated ammonium sulfate was added to the supernatant to obtain a final concentration of $40 \%$ and incubated for $1 \mathrm{~h}$ at $4^{\circ} \mathrm{C}$. The precipitate was then collected as described above. The presence of viral associated antigen in the pellet was determined by dot-blotting and Western blotting.

SDS-PAGE and Western blot analysis. Haemolymph and gill extracts from non-infected and infected shrimp were separated by $7.5 \%$ SDS-PAGE according to the method described in the BioRad manual (Laemmli 1970). Samples were electrophoresed for $6 \mathrm{~h}$ at $30 \mathrm{~V}$, and gels were stained using Coomassie Brilliant Blue $\mathrm{R}-250$.

For Western blotting, the samples separated by SDSPAGE were electroblotted at $30 \mathrm{~V}$ onto a nitrocellulose membrane (BioRad). The nitrocellulose membrane was incubated in 5\% Blotto for $10 \mathrm{~min}$, treated with 1:200 V3-2B conditioned media for $4 \mathrm{~h}$ and then processed as described above in 'Dot-blots'.

For locating the relative position of V3-2B immunoreactive bands, the same nitrocellulose membrane was reprobed with an MAb specific to haemocyanin subunits PMVS-22 (Longyant et al. 2000) and developed in the substrate without cobalt choride.

MAb class and subclass determination. Class and subclass of mouse immunoglobulin produced by hybridomas were determined by sandwich ELISA using Zymed's Mouse MonoAb ID Kit (HRP) in accordance with the instructions provided by the kit manufacturer.

\section{RESULTS AND DISCUSSION}

Histological analysis of the shrimp experimentally injected with the WSSV preparation used revealed that they were dually infected with WSSV and YHV (Fig. 1A). However, the control shrimp from these tests (gill example, Fig. 1B) showed no histological signs of viral infection. YHV appeared to dominate in the infection group (Fig. 1A), judging from the large number of densely staining karyorhectic and pycnotic nuclei typical of YHV infection (Lightner 1996) and the fewer nuclei typical of WSSV infection. In addition, most of the WSSV infected nuclei showed Cowdry A-type inclusions characteristic of early stages of viral development (Wongteerasuypaya et al. 1995).

One consequence of the impure antigen was a low yield of hybridoma fusions that gave specific antibodies. Fusion trials produced about 600 wells containing hybridoma cells, from 30 micro-culture plates. The first screening by dot-blotting against extracts from non-infected and infected gills in both native and SDS treated forms revealed 2 positive hybridoma clones (V3-2B and V219) that reacted with infected gill 


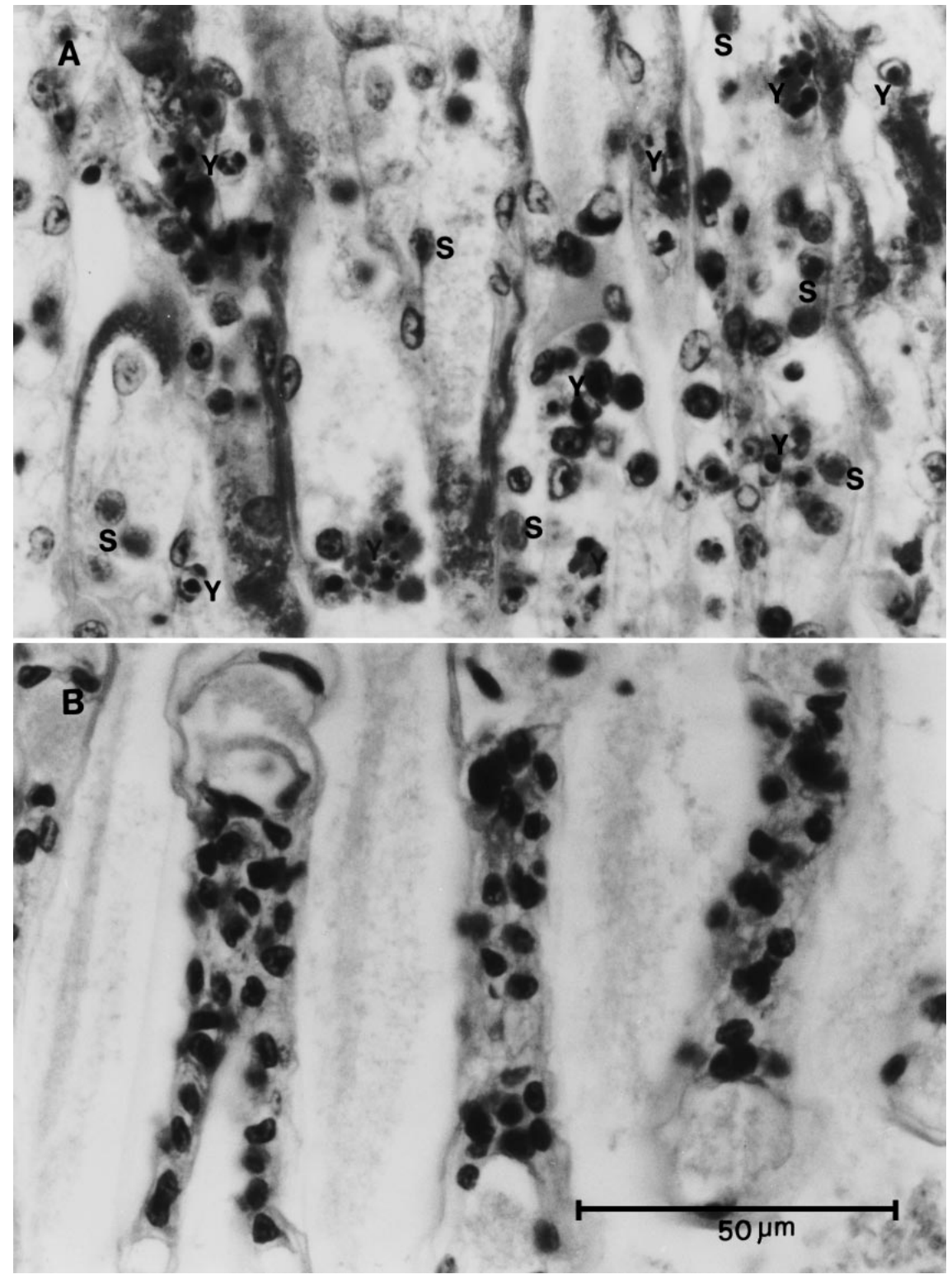

Fig. 1. Penaeus monodon. Histology and immunocytochemistry of gill tissues from the experimentally infected and control shrimp used to immunize the mice for MAb production. Tissues were and treated with MAb V3-2B and stained with H\&E. (A) Gill tissue from infected shrimp showing the presence of histopathology characteristic of both YHV (Y) and WSSV (S) infection. The YHV infected cells showed typical condensed chromatin with karyorhectic and pycnotic nuclei, and their cytoplasm was immunoreactive (distinctive brown staining against the pink and blue H\&E background, but seen in this blackand-white photomicrograph as a dark gray). Immunoreactivity is also seen in the haemolymph. The WSSV infected cells show hypertrophied nuclei with Cowdry A-type nuclear inclusions and they are not immunoreactive. (B) Gill tissue from the control shrimp injected with carrier solution. No histopathology characteristic of YHV or WSSV infection can be seen. Nor is there any immunoreactivity with MAb V3-2B evident

extracts in both native and denatured forms but showed low cross-reactivity with gill extracts from non-infected shrimp (Fig. 2). Using immunocytochemical screening (see below), both antibodies showed cytoplasm immunostaining in large numbers of cells in infected gill tissues. Antibodies produced from many other clones (example 2-5D in Fig. 2) showed reactivity against gill extracts from both non-infected and infected shrimp and these were discarded. The 2 positive hybridoma clones (V3-2B and V219) were recloned, expanded, and cryopreserved. Since V3-2B antibody produced more intense staining with dotblotting than V219 (Fig. 2), it was used for all subsequent tests.

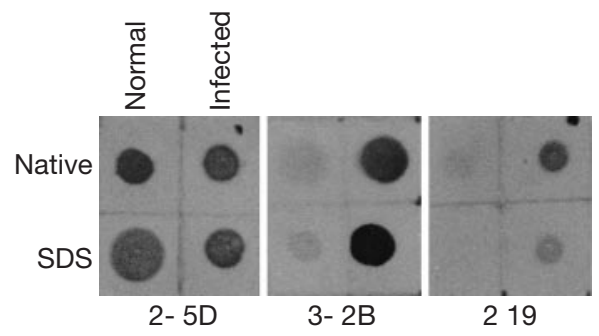

Fig. 2. Monoclonal antibody (MAb) screening by dot-blotting. Examples of 3 types of MAb reaction are shown for MAb obtained during this study. MAb 2-5D reacted with both normal and experimentally infected shrimp and is an example of the type discarded. MAb V3-2B and V219 are examples of MAb that gave specific reactions to infected tissues. MAb V3-2B gave the strongest differential reaction and so it was used in all subsequent tests 
Our trials produced relatively low fusion yields (typical yields in a previous experiment were $>3000$ clones fusion $^{-1}$ with other antigens) (Longyant et al. 2000). Improved hybridoma yields should produce greater numbers of clones that yield specific antibodies.

Immunocytochemical studies using V3-2B antibody with gill tissues from infected shrimp clearly revealed that viral immunoreactivity was found in the cytoplasm of epithelial cells and haemocytes showing the karyorhectic or pycnotic nuclei typically characteristic of YHV infection (Fig. 1A) (Chantanachookin et al. 1993, Flegel et al. 1997). Hypertrophied nuclei and Cowdry A-type nuclear inclusions found in the same sections but typical for WSSV infection (Flegel et al. 1997, Tapay et al. 1997) did not show any immunoreactivity with the V3-2B antibody (Fig. 1A). In addition, im- munocytochemical studies of tissues from shrimp experimentally infected singly with YHV or WSSV revealed that tissues from YHV infected shrimp reacted positively with the antibody (example gill, Fig. 3A) while those from WSSV infected shrimp did not (example gill, Fig. 3B). Nor did tissues from normal uninfected shrimp (Fig. 1B).

Since the control shrimp showed no histological or immunocytochemical indication of YHV presence, it is most likely that the WSSV infected shrimp originally used to prepare the WSSV inoculum in this study were dually infected with WSSV and YHV, although gross signs of WSSV infection dominated. Dual infections of these 2 viruses have been previously reported (Mohan et al. 1998, Park et al. 1998) and are considered to be relatively frequent in Thailand (T. W. Flegel pers.

Fig. 3. Penaeus monodon. Immunocytochemistry of MAb V3-2B in tissues of normal control shrimp and infected shrimp from experimental trials with single viral infections of YHV or WSSV as confirmed by histopathology. (A) Gill tissue of YHV infected shrimp showing a positive immunochemistry reaction in the haemolymph and in the cytoplasm of cells showing typical YHV histopathology (Y). (B) Gill tissue of WSSV infected shrimp showing a negative immunochemistry reaction in the haemolymph and in cells showing typical WSSV histopatho$\operatorname{logy}(\mathrm{S})$

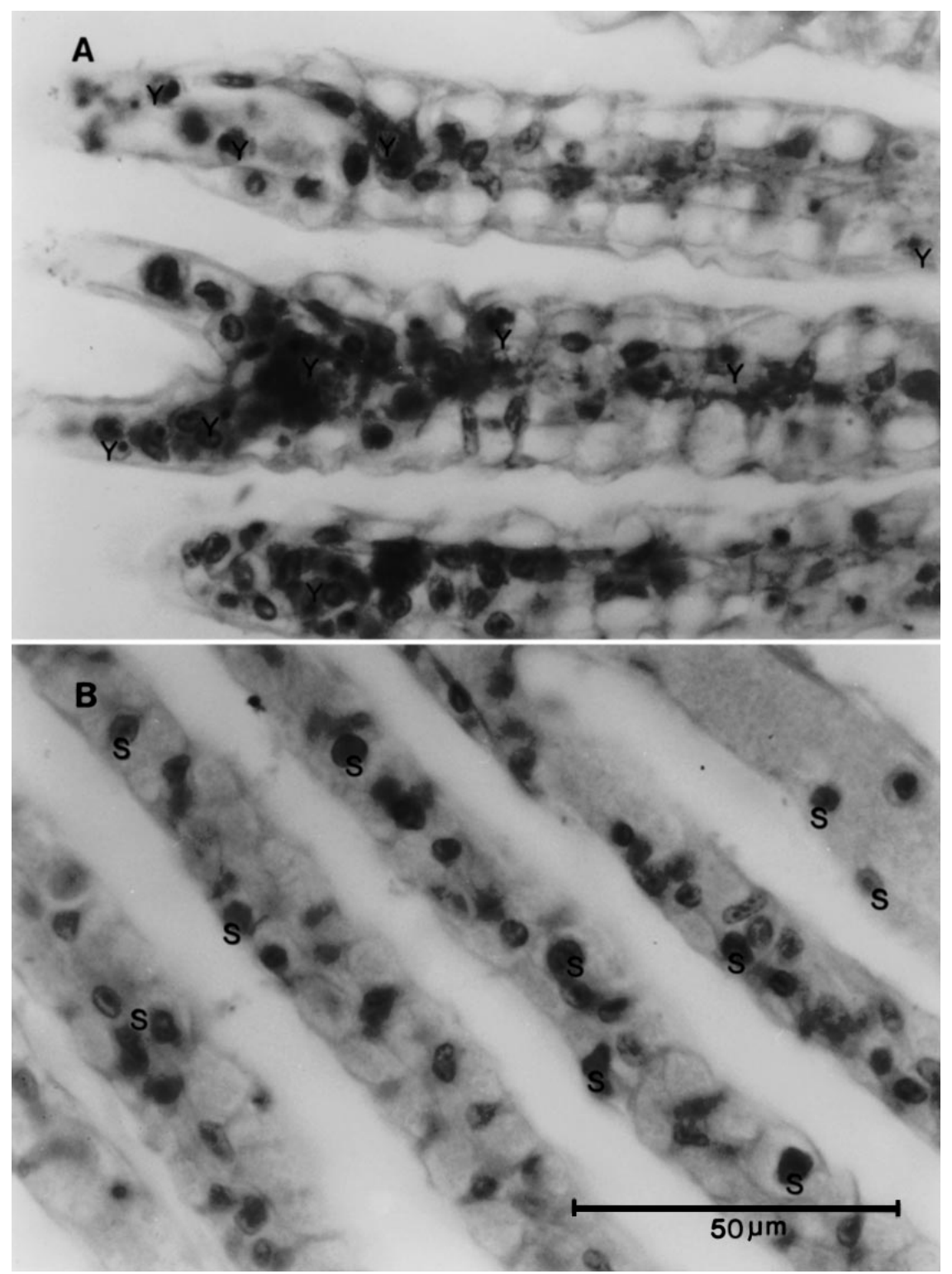




\section{A. Direct Spot}

\section{Dilutions}

1:

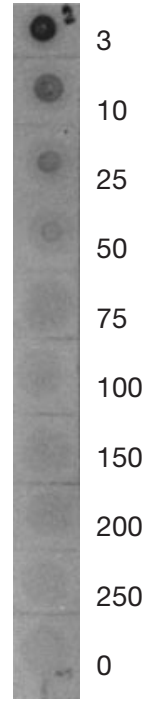

\section{B. Ammonium Sulfate Precipitation}

20x 40x 60x Dilutions

1:
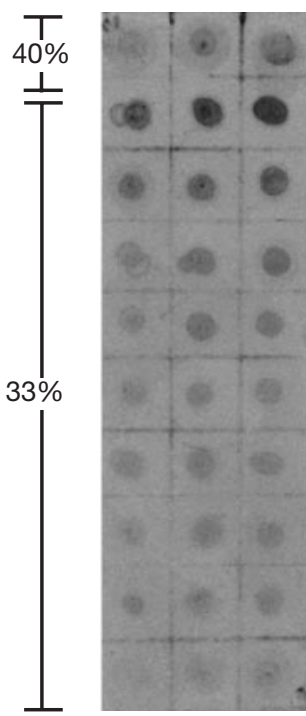

100

100

500

750

1000

1500

2000

3000

5000

0
Fig. 4. Penaeus monodon. Dot-blotting of infected haemolymph serially diluted with haemolymph from non-infected shrimp and tested using MAb V3-2B. Diluted haemolymph was (A) applied directly or (B) concentrated (20, 40 or 60 times) by $33 \%$ ammonium sulfate precipitation. Only the supernatant of the first dilution was further precipitated with $40 \%$ ammonium sulfate. Numbers in the right-hand columns are dilution factors and the ' 0 ' represents haemolymph from noninfected shrimp used as a diluent

comm.). Dual and multiple infections are a constant risk when experimental shrimp are available from production ponds only. This complication could have posed difficulties if the objective had been to produce polyclonal antibodies. However, the original work plan did not involve viral purification because the highly specific nature of monoclonal antibodies reduces the importance of antigen purity. Indeed, successful MAb preparation was achieved even though a mixed viral antigen was inadvertently used, and this exemplifies the power of the MAb technique.
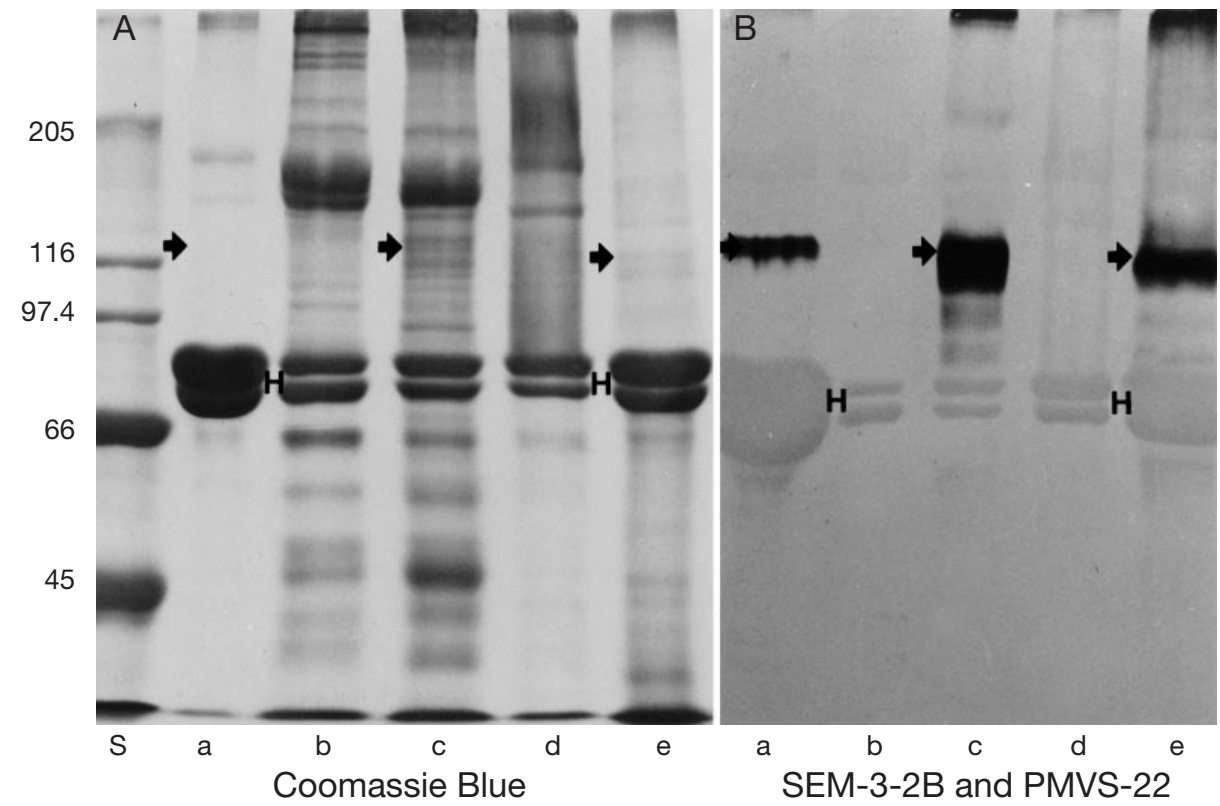

Fig. 5. Penaeus monodon. SDS-PAGE and Western blot analysis of haemolymph and gill extracts. The numbers on the left-hand side indicate molecular weights of marker proteins (S). (A) Coomassie blue stained gel of protein extracts. (s) Molecular weight marker; (a) crude haemolymph from infected shrimp; (b) $33 \%$ ammonium sulfate precipitate from haemolymph of non-infected shrimp; (c) $33 \%$ ammonium sulfate precipitate from haemolymph of infected shrimp; (d) $40 \%$ ammonium sulfate precipitate from haemolymph after $33 \%$ precipitation; (e) crude gill extract from infected shrimp. (B) Western blot probed with MAb V3-2B (heavy staining = black in the color photograph) and re-probed with MAb PMVS-22, an antibody specific to haemocyanin (H) (light staining $=$ yellow in the color photograph). Band numbers correspond to those in (A). Strong positive reactions (black) to MAb V3-2B were seen only for experimentally infected shrimp (lanes $\mathrm{a}, \mathrm{c}$ and e) at band positions corresponding to those in the Coomassie stained gel at approximately $135 \mathrm{kD}$. There was no reaction in the $40 \%$ ammonium sulfate fraction, indicating that the reactive protein had been precipitated at $33 \%$. The immunoreactive bands at the top of lanes a, c and e were the result of undissolved residues in the sample preparations 
In dot-blotting of serially diluted haemolymph from infected shrimp using the indirect immunoperoxidase method, the V3-2B antibodies detected the antigen with strong reactivity up to 1:50 dilution. When infected haemolymph was diluted by haemolymph from non-infected shrimp and concentrated by ammonium sulfate precipitation, viral associated antigen was detected up to 1:1000-1:1500 dilutions. However, some background staining was observed at all dilutions, including samples of haemolymph from uninfected shrimp (Fig. 4). Modified methods using sandwich ELISA combined with 2 or 3 amplification steps should increase sensitivity several fold and may be able to reduce the background to undetectable levels. This modification and precise identification and quantification of viral associated antigen is in progress.

The Western blot analysis of $33 \%$ ammonium sulfate precipitated haemolymph and gill extract from infected shrimp exhibited a single reactive band at approximately $135 \mathrm{kD}$ (Fig. 5). This corresponded to the molecular mass of the YHV envelope glycoprotein reported by Nadala et al. (1997). The present work did not resolve whether the antibody reacted with a viral structural protein or with a viral specific antigen produced by the host during the course of YHV infection. The Western blot results and reference to the earlier work by Nadala et al. (1997) support the former possibility, but final confirmation would require tests of the $\mathrm{MAb}$ with purified viral structural proteins. In any case, V3-2B reacted only with tissues of shrimp infected with YHV. Thus, the ambiguity regarding the specific target for V3-2B does not detract from its utility for detection of YHV infections.

As shown in Fig. 5, V3-2B antibody had a high specificity to viral associated antigen and showed exceptionally low cross-reactivity with various proteins from uninfected shrimp tissues. Coomassie blue staining of SDS-PAGE and Western blot analysis using MAb specific to haemocyanin-PMVS-22 revealed that various proteins were present in the mixture utilized in this analysis and immunization (Fig. 5).

No V3-2B immunoreactivity was observed in either haemolymph from non-infected shrimp or in $40 \%$ ammonium sulfate precipitated haemolymph (after $33 \%$ precipitation) from infected shrimp (Fig. 5). This evidence indicated that most of the viral associated antigen was readily separated by $33 \%$ ammonium sulfate treatment. Similar results were obtained with the dot-blot experiments (Fig. 4B).

Both antibodies belonged to the IgG2a subclass. This was different from the IgM reported by other laboratories working on crustacean viruses. The IgM antibodies reacted non-specifically with components of non-infected shrimp tissue samples, resulting in false positive reactions in ELISA-based assays (Lightner \&
Redman 1998). IgG has advantages in that it has higher affinity, higher specificity and lower cross-reactivity than IgM. Our IgG-MAb immunocytochemistry test has proven effective for in situ screening of archived blocks of paraffin embedded shrimp tissues for the presence of YHV, and it serves as an independent confirmatory test to histopathological diagnosis. It has an advantage over in situ nucleic acid hybridization procedures in that it is not vulnerable to RNA digestion by the acid in Davidson's fixative. Alternative labeling of the GAM-HRP with fluorescein and counterstaining with propidium iodide should allow for rapid fluorescence detection. Hopefully it will be possible to use the MAb for development of simple and lowcost tests for routine diagnosis by modestly equipped field laboratories or for pond-side tests by farmers.

Acknowledgements. We thank T. W. Flegel for kindly providing YHV- and WSSV-infected tissues from experimental infections for antibody specificity tests. This work was partially supported by the Thailand Research Fund (TRF) to P.M.

\section{LITERATURE CITED}

Chantanachookin C, Boonyaratpalin S, Kasornchandra J, Direkbusarakom S, Ekpanithapong U, Supamataya K, Sriurairatana S, Flegel TW (1993) Histology and ultrastructure reveal a new granulosis-like virus in Penaeus monodon affected by yellow head disease. Dis Aquat Org 17:145-157

Cowley JA, Dimmock CM, Wongteerasupaya C, Boonsaeng V, Panyim S, Walker PJ (1999) Yellow head virus from Thailand and gill-associated virus from Australia are closely related but distinct prawn viruses. Dis Aquat Org 36:153-157

Flegel TW, Boonyaratpalin S, Withyachumnarnkul B (1997) Progress in research on yellow-head virus and white-spot virus in Thailand. In: Flegel TW, MacRae IH (eds) Diseases in Aquaculture III. Asian Fisheries Society, Manila, p 285-302

Hudson L, Hay FC (1976) Practical immunology. Blackwell Scientific Publications, London

Kanchanaphum P, Wongteerasupaya C, Sitidilokratana N, Boonsaeng V, Panyim S, Tassanakajon A, Withyachumnarnkul B, Flegel TW (1998) Experimental transmission of white spot syndrome virus (WSSV) from crab to shrimp Penaeus monodon. Dis Aquat Org 34:1-7

Köhler G, Milstein C (1976) Derivative of specific antibodyproducing tissue culture and tumor cell fusion. Eur $\mathrm{J}$ Immunol 6:511-519

Laemmli UK (1970) Cleavage of structural proteins during the assembly of the head of bacteriophage T4. Nature 227: $680-685$

Lightner DV (ed) (1996) A handbook of pathology and diagnostic procedures for diseases of penaeid shrimp. World Aquaculture Society, Baton Rouge

Lightner DV, Redman RM (1998) Shrimp disease and current diagnosis methods. Aquaculture 164:201-220

Loh PC, Cesar E, Nadala B, Tapay LM, Lu Y (1998) Recent developments in immunological-based and cell culture protocols for the specific detection of shrimp viral pathogens. In: Flegel TW (ed) Advances in shrimp biotechnol- 
ogy, Proceedings to the Special Session on Shrimp Biotechnology, 5th Asian Fisheries Forum, The National Center for Genetic Engineering and Biotechnology, Thailand, Multimedia Asia Co. Ltd, Bangkok, p 255-259

Longyant S, Sithigorngul P, Thampalerd N, Sithigorngul W, Menasaveta P (2000) Characterization of vitellin and vitellogenin of giant tiger prawn Penaeus monodon using monoclonal antibodies specific to vitellin subunits. Invertebr Reprod Dev (in press)

Mohan CV, Shankar KM, Kulkarni S, Sudha PM (1998) Histopathology of cultured shrimp showing gross signs of yellow-head syndrome and white spot syndrome during 1994 Indian Epizootics. Dis Aquat Org 34:9-12

Mosmann TR, Bauman R, Williamson AR (1979) Mutations affecting immunoglobulin light chain secretion by myeloma cells I. Functional analysis by cell fusion. Eur J Immunol 9:511-516

Nadala ECB Jr, Tapay LM, Loh PC (1997) Yellow-head virus: a rhabdovirus-like pathogen of penaeid shrimp. Dis Aquat Org 31:141-146

Nadala ECB Jr, Tapay LM, Loh PC (1998) Characterization

Editorial responsibility: Timothy Flegel,

Bangkok, Thailand of a non-occluded baculovirus-like agent pathogenic to penaeid shrimp. Dis Aquat Org 33:221-229

Park JH, Lee YS, Lee S, Lee Y (1998) An infectious viral disease of penaeid shrimp newly found in Korea. Dis Aquat Org 34:71-75

Tapay LM, Lu Y, Gose RB, Brock JA, Loh PC (1997) Infection of white-spot Baculovirus-like virus (WSBV) in two species of penaeid shrimp Penaeus stylirostris (Stimpson) and P. vanamei (Boone). Diseases in Asian Aquaculture III. Asian Fisheries Society, Manila, p 297-302

Wongteerasupaya C, Vickers JE, Sriurairatana S, Nash GL, Akarajamorn A, Boonsaeng V, Panyim S, Tassanakajon A, Withyachumnarnkul B, Flegel TW (1995) A non-occluded, systemic baculovirus that occurs in cells of ectodermal and mesodermal origin and causes high mortality in the black tiger prawn Penaeus monodon. Dis Aquat Org 21:69-77

Wongteerasupaya C, Thongchuea W, Boonsaeng V, Panyim S, Tassanakajon A, Withyachumnarnkul B, Flegel TW (1997) Detection of yellow-head virus (YHV) for Penaeus monodon by RT-PCR amplification. Dis Aquat Org 31: 181-186

Submitted: November 2, 1999; Accepted: March 30, 2000 Proofs received from author(s): July 4, 2000 